\title{
OPTIMAL DESIGN OF RESTRAINED SHEET PILE WALLS
}

\author{
Ahmed Mousa ${ }^{1}$, Remon Isaac ${ }^{2}$, Mohamed A. Eid ${ }^{3}$ and Ahmed S. Mohamed ${ }^{4}$ \\ 1 Associate Professor \\ 2 Associate Professor - RemonIsaac@gmail.com \\ 3 Associate Professor - M.Eid@mu.edu.eg \\ $4 \quad$ Post Graduate Student - a.salah.civil@gmail.com \\ Faculty of Engineering - Minia University, Egypt
}

\begin{abstract}
:
Restrained shoring wall represents a commonly used economic solution for vertical deep excavation, when open cuts with side slopes are not allowed. It is mainly used to avoid failure that may be accompanied by considerable settlements, tilting or by bearing capacity failure of nearby foundations. The cost of these systems mainly depended on soil type and excavation depth. In this research, strutted shoring systems are analyzed and designed for sandy soil conditions and excavation depth $15 \mathrm{~m}$. The system is optimized using Genetic Algorithm. Finite Element Method is used for the analysis. The designed problem is formulated as a non-linear mathematical programming problem using FORTRAN 95. The developed model is used for parametric study to investigate the influence of different design parameters on the system cost. Genetic Algorithm, is used to perform the optimization study based on the minimum cost. The optimization process aims to minimize the system cost considering both deformation and stress constraints for the ground soil and construction material.
\end{abstract}

Keywords: Restrained Sheet Pile Wall, Optimization, Genetic Algorithm, Finite Element Analysis, Deep Excavation.

\section{INTRODUCTION}

Deep excavation is often necessary in urban area for the best use of the underground space. Design of the supported deep excavations is a critical issue because it requires an accurate prediction of soil properties, support system response, and effect on adjacent structures activities.
Therefore, studying stability of excavations using suitable constitutive model is a very important issue. The purpose of a deep excavation support system is to provide a lateral support of the excavated sides and to limit the ground deformations around the surrounding soil. Excavation support structure for deep excavations consists of retaining walls and wall supports. Many 
types of walls and wall supports can be used to retain the deep excavation sides. Concrete diaphragm walls, sheet piles, soldier piles, and adjacent piles are the most common types of the retaining walls; while, struts, and tiebacks are the most common types of the supporting measure.

There are many factors effect on stability of deep excavations in soils. These factors can be classified into three categories based on construction stages; site conditions, design parameters, and construction parameters. These factors are highly influenced by soil behavior at the element level.

In 1981, a few trials were carried out on strutted sheet pile wall, to investigate the effect of the strut stiffness in an attempt to reach a better design. It found that, increasing the stiffness of the supporting measure reduces the lateral deformation $40 \%$ as shown in Figure 1, [1].

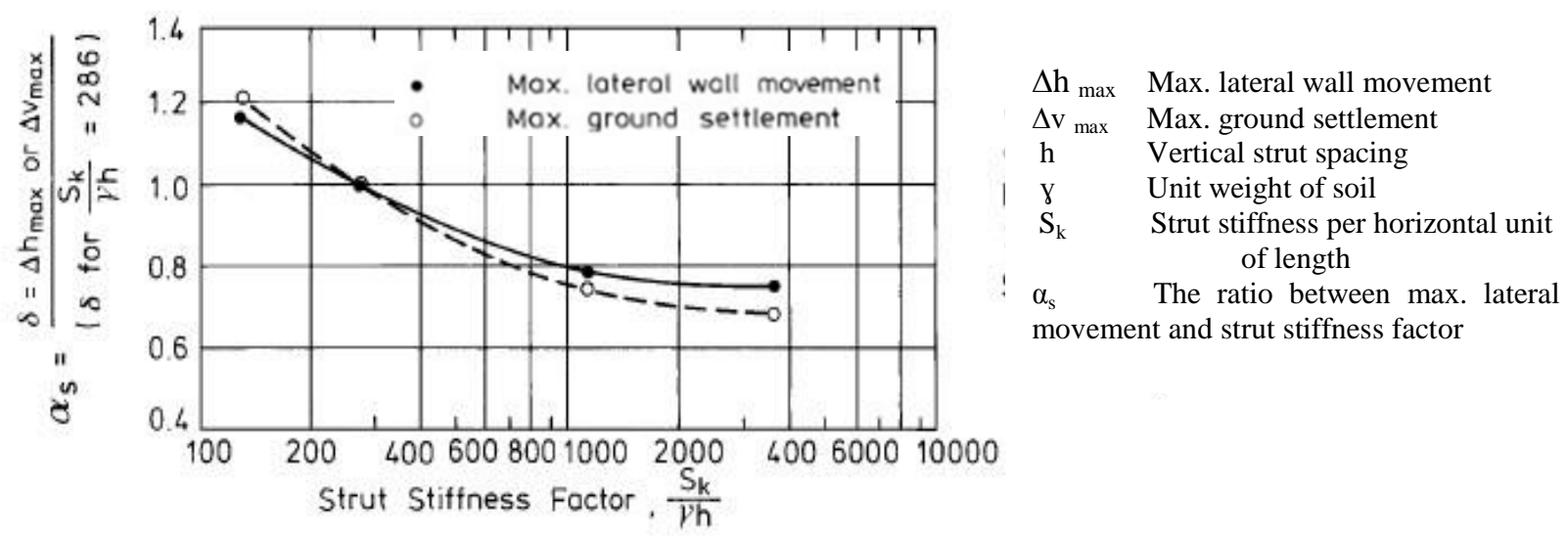

Fig.1. The effect of the strut stiffness on the maximum lateral deformation of the wall and the maximum settlement.

In 2012, a parametric study is carried out to investigate the influence of different design parameters, such as strut stiffness, wall thickness, strut arrangement and the embedded depth of the wall on strut force, maximum moment developed in the wall, maximum lateral displacement of the wall, and maximum vertical displacement of ground surface. It was observed that, for a particular wall thickness and strut stiffness, different strut arrangements produced different results for maximum strut force, maximum moment, maximum horizontal wall displacement, and maximum vertical ground surface displacement, [2].

Recently, in 2016, the feasibility and efficiency of Genetic Algorithm application were investigated in the studied geotechnical problem and the influence of Genetic Algorithm operations on the cost minimization is showed. A heuristic optimization technique, Genetic Algorithms, is applied to the strutted sheet pile wall design. They found that the GAs technique is successful in the presented optimization problem of deep excavation and increasing the mutation probability did not help enhancing the progression. The developed model is used for parametric study to investigate the influence of different design parameters on the system cost, [3].

\section{GENETIC ALGORITHMS}

A basic element of the Biological Genetics is the chromosome. Chromosomes crossover each other and mutate themselves and new set of chromosomes is generated. Based on the requirement, some of the chromosomes survive. This is the cycle of one generation in Biological Genetics. The above process is repeated for many generations and finally the best set of chromosomes based on the requirement will be available. This is the natural process of Biological Genetics. The mathematical algorithm equivalent to the above behavior used as the optimization technique is called as Artificial Genetic Algorithm [4]. Genetic algorithms can be defined as a search algorithm based on the mechanics of natural selection and natural genetics. They combine survival of the 
fittest among string structures with structured yet randomized information exchange to form a search algorithm with some of the innovative flair of human search [5].

As in a biological system submitted to external constraints, the fittest members of the population are selected to survive and given better chances of reproducing and transmitting part of their genetic heritage to the next generation. A new population is then created by recombination of parental genes. It is expected that some members of this new population will have acquired the best characteristics of both parents and, being better adapted to the environmental conditions, will provide an improved solution to the considered problem. After it has replaced the original population, the new group is submitted to the same evaluation procedure, and later generates its own offspring. The process is repeated many times, until elite members of a given generation share the same genetic heritage. These members, who are often quite different from their ancestors, possess genetic information that corresponds to the best solution to the optimization problem [6].

\section{PROBLEM DESCRIPTION}

The design optimization problem addressed herein is used for parametric study to show the influence of different design parameters, such as wall embedded depth, wall section and struts numbers, struts positions and sections, those lead to pre-specified safe lateral deformation during excavation and acceptable induced stresses in soil and structural elements to have minimum system cost. In this study a very loose sandy soil condition with excavation depth $15 \mathrm{~m}$ is studied. On the other side; two different wall material type (sheet pile and concrete diaphragm wall) are studied to compare the cost based on the different systems. Figure 2 shows a half section for the structural system and geometrical variables considered.

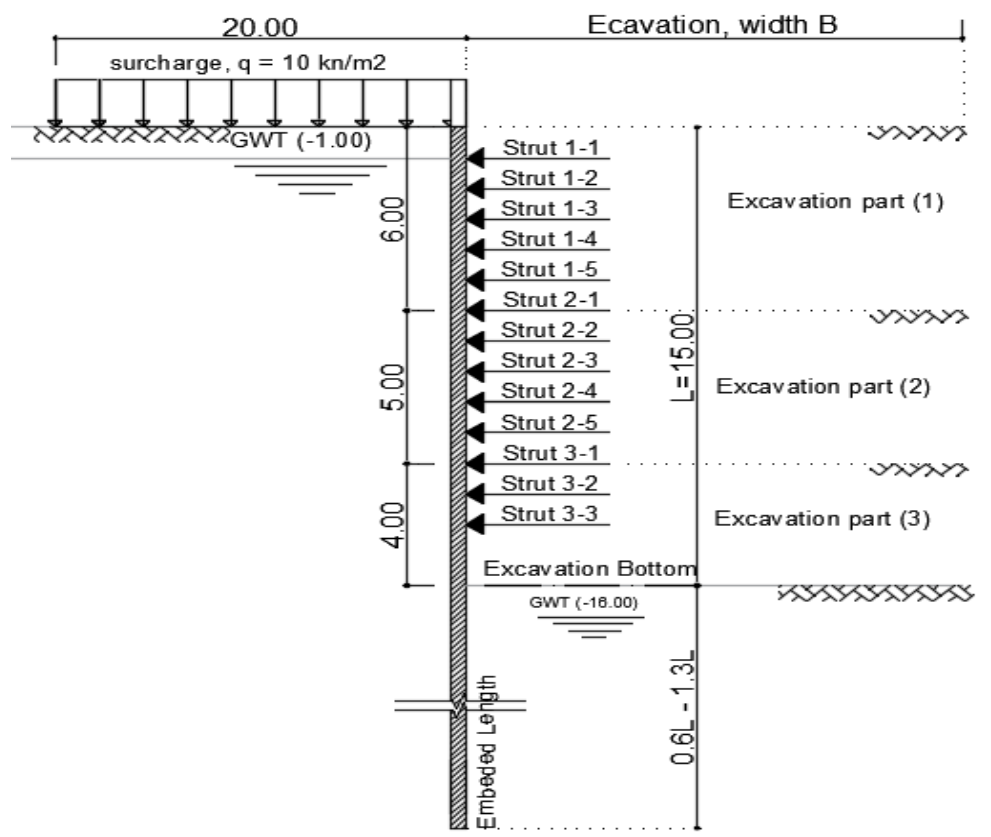

Fig.2: Problem layout and geometrical variables.

Hence, the objective function can be stated as:

minimize $f(X)$

find $\quad X \in R_{k}$ $\mathrm{i}=1,2, \ldots, \mathrm{n}$ and

subject to $g_{i}(X) \leq 0$,

$\mathrm{X}_{\mathrm{j}}^{\mathrm{L}} \leq \mathrm{X}_{\mathrm{j}}^{\mathrm{u}}, \quad \mathrm{j}=$ 
Where: $\mathrm{X}$ is the vector of design variables; $\mathrm{f}$ $(\mathrm{X})$ is the objective function; $\mathrm{g}_{\mathrm{i}}(\mathrm{X})$ is the performance constraints; and $\mathrm{X}_{\mathrm{j}}^{\mathrm{L}}$ and $\mathrm{X}_{\mathrm{j}}^{\mathrm{u}}$ refer to the lower and upper bounds on the design variables, respectively. The objective function here is the cost of the system and can be expressed as:

- For Sheet Pile Wall

Min $\mathrm{T}_{\text {cost }}=\gamma_{s}\left(\mathrm{~L}_{W} \mathrm{~S}_{W}+\mathrm{L}_{s} \mathrm{~S}_{s} \mathrm{~N}_{s}\right)$

- For Concrete Diaphragm Wall

Min $\mathrm{T}_{\text {cost }}=\mathrm{c}_{\text {steel }}+\mathrm{c}_{\text {conc }}$

$\mathrm{C}_{\text {steel }}=\mathrm{L}_{s} \mathrm{~S}_{s} \mathrm{Ns}$ and $\mathrm{C}_{\text {conc }}=\mathrm{L}_{\mathrm{w}} * \mathrm{~A}_{\text {Conc. }}$.

Where: $\gamma_{\mathrm{s}}$ is steel density, $\mathrm{L}_{\mathrm{w}}$ is the sheet wall total length, $S_{w}$ is the sheet wall crosssectional area, $\mathrm{L}_{\mathrm{s}}$ is the strut length, $\mathrm{S}_{\mathrm{s}}$ is the strut cross-sectional area, $\mathrm{N}_{\mathrm{s}}$ is the struts number. $\mathrm{A}_{\text {conc. }}$ is the diaphragm wall crosssectional area, $\mathrm{C}_{\text {steel }}$ is the cost of struts and $\mathrm{C}_{\text {conc }}$ is the cost of concrete.

There are two types of constraints; allowable stresses and deformation limits:

- Stress condition: the induced stresses in soil, wall and struts, should be within allowable limits.

$\mathrm{g}_{1 \mathrm{i}}=\left|\sigma_{\mathrm{i}}\right|-\sigma_{\text {all }} \leq 0, \quad \mathrm{i}=1,2, \ldots . \mathrm{m}$

Where: $g_{1 i}$ is the stress condition, $\sigma_{i}$ is the induced stresses and $\sigma_{\text {all }}$ is the allowable stresses.

- Deformation condition: lateral displacements in sheet wall during excavation should not exceed the pre-specified limits $(0.05 \mathrm{~L})$, where $\mathrm{L}$ is the excavation depth.

$\mathrm{g}_{2 \mathrm{i}}=\left|\Delta_{\mathrm{i}}\right|-\Delta_{\text {all }} \leq 0, \quad \mathrm{i}=1,2, \ldots \ldots \mathrm{m}$

Where: $g_{2 i}$ is the deformation condition, $\Delta_{i}$ is the induced lateral displacement and $\Delta_{\text {all }}$ is the allowable displacement.

\section{Design Variables:}

In this research, six design variables, listed here to find the minimum system cost: wall material type; wall embedded depth; wall section and strut numbers; section and position.

1. Wall material type: steel sheet pile and concrete diaphragm wall are considered in this study.

2. Wall section: the section is selected from 8 different alternatives according to the wall type. For the sheet pile wall, properties of sections are shown in Table [1]. For the concrete diaphragm wall, the section is started with thickness $40 \mathrm{~cm}$, with $10 \mathrm{~cm}$ increment step as shown in Table [2].

3. Wall embedded depth: ranges from (0.6 to 1.3$) \mathrm{L}$, where $\mathrm{L}$ is the excavation depth, with $1 \mathrm{~m}$ increment step is examined. In this case, the wall embedded length is started from $9 \mathrm{~m}$ to $20 \mathrm{~m}$.

4. Strut section: 10 different pipes from Egyptian Standard Steel Sections are used as shown in Table [3].

5. Strut numbers: numbers of struts mainly depend on the excavation depth. In the case of $15 \mathrm{~m}$ excavation depth, Two or three struts may be used, the number of struts is shown in Figure (2).

6. Strut position: different alternative positions for struts are assumed:

- First strut position: 5 different alternative positions for first strut are considered; at $1,2,3,4$ or $5 \mathrm{~m}$ depth from ground surface.

- Second strut position: 5 different alternative positions for $2^{\text {nd }}$ strut are considered; at $6,7,8,9$ or $10 \mathrm{~m}$ depth from ground surface.

- Third strut existence/position: this 
one has an optional

existence with 2

11or $12 \mathrm{~m}$ from

alternative positions at

ground surface.

Table 1: Alternative sections for sheet pile wall

\begin{tabular}{ccccccc}
\hline $\begin{array}{c}\text { Section } \\
\text { No. }\end{array}$ & $\begin{array}{c}\text { Section } \\
\text { Name }\end{array}$ & $\begin{array}{c}\text { Width } \\
(\mathrm{mm})\end{array}$ & $\begin{array}{c}\text { Height } \\
(\mathrm{mm})\end{array}$ & $\begin{array}{c}\text { Back thick- } \\
\text { ness }(\mathrm{mm})\end{array}$ & $\begin{array}{c}\text { Web thick- } \\
\text { ness }(\mathrm{mm})\end{array}$ & $\begin{array}{c}\text { Inertia } \\
\left(\mathrm{cm}^{4} / \mathrm{m}\right)\end{array}$ \\
\hline 1 & Larssen 600 & 600 & 150 & 10.0 & 9.9 & 4050 \\
2 & Larssen 601 & 600 & 310 & 8.0 & 6.8 & 12245 \\
3 & Larssen 602 & 600 & 310 & 8.7 & 8.4 & 13640 \\
4 & Larssen 603 & 600 & 310 & 10.2 & 8.5 & 19375 \\
5 & Larssen 604 & 600 & 380 & 10.5 & 9.2 & 31675 \\
6 & Larssen 605 & 600 & 420 & 13.0 & 9.2 & 43890 \\
7 & Larssen 606 & 600 & 435 & 14.9 & 9.4 & 55900 \\
8 & Larssen 607 & 600 & 452 & 19.5 & 10.8 & 73900 \\
\hline
\end{tabular}

Table 2: Alternative sections for concrete diaphragm wall

\begin{tabular}{ccccc}
\hline $\begin{array}{c}\text { Section } \\
\text { No }\end{array}$ & $\begin{array}{c}\text { Thickness } \\
(\mathrm{cm})\end{array}$ & $\begin{array}{c}\text { Length } \\
(\mathrm{cm})\end{array}$ & $\begin{array}{c}\text { Area } \\
(\mathrm{cm} 2)\end{array}$ & $\begin{array}{c}\text { Inertia } \\
(\mathrm{cm} 4 / \mathrm{m})\end{array}$ \\
1 & 40 & & 4000 & $533^{*} 10^{4}$ \\
2 & 50 & & 5000 & $1041^{*} 10^{4}$ \\
3 & 60 & & 6000 & $1800^{*} 10^{4}$ \\
4 & 70 & \multirow{2}{*}{100} & 7000 & $2858^{*} 10^{4}$ \\
5 & 80 & & 8000 & $4266^{*} 10^{4}$ \\
6 & 90 & & 9000 & $6075^{*} 10^{4}$ \\
7 & 100 & & 10000 & $8333^{*} 10^{4}$ \\
8 & 110 & & 11000 & $11091^{*} 10^{4}$ \\
\hline
\end{tabular}

Table 3: Alternative sections for struts pipes

\begin{tabular}{ccccc}
\hline $\begin{array}{c}\text { Section } \\
\text { No. }\end{array}$ & $\begin{array}{c}\text { Pipe } \\
\text { No. }\end{array}$ & $\begin{array}{c}\text { Thickness } \\
(\mathrm{mm})\end{array}$ & $\begin{array}{c}\text { Area } \\
\left(\mathrm{cm}^{2}\right)\end{array}$ & $\begin{array}{c}\text { Radius of } \\
\text { gyration }(\mathrm{cm})\end{array}$ \\
\hline 1 & 325 & 8 & 79.7 & 11.2 \\
2 & 325 & 10 & 99.0 & 11.1 \\
3 & 368 & 8 & 90.5 & 12.7 \\
4 & 368 & 10 & 112.0 & 12.7 \\
5 & 419 & 10 & 128.0 & 14.5 \\
6 & 419 & 12 & 153.0 & 14.4 \\
7 & 529 & 9 & 147.0 & 18.4 \\
8 & 529 & 10 & 163.0 & 18.4 \\
\hline
\end{tabular}

boundary condition, vertical and horizontal

\section{NUMERICAL MODELING}

The numerical analysis was carried out as a plane strain problem using the structural analysis program FINAL [7]. The soil media is modeled using six-node Linearly varying Strain Triangular (LST) element. The shoring wall is presented by six-node beam elements (Beam6) and the strut is modeled by two-node link member (Beam2). For movements are prevented at the bottom of the model, while only the horizontal movements are prevented at both sides. Ground water is presented with its net lateral load. A half section mesh is used in the analysis to reduce computation time. Figure (3) shows the Finite Elements mesh used for simulation with close views for excavation area before and after excavation. 


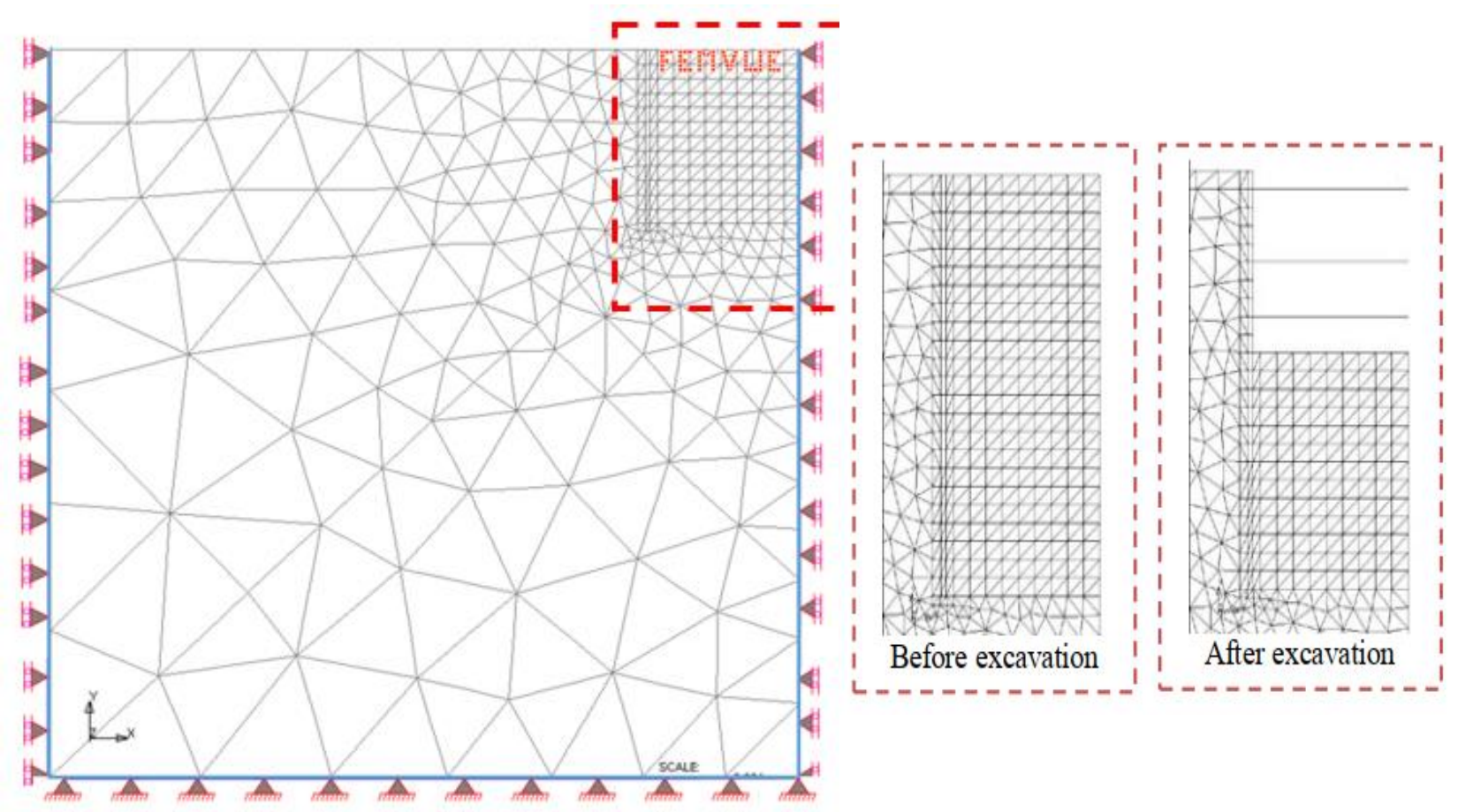

Fig.3 : Finite elements simulation mesh

\section{Geotechnical Parameters}

A very loose sand soil condition is examined, in order to investigate the influence of soil parameter on optimal values. Characteristic and mechanical properties for this soil type according to the ECP [202/3] are given in Table (4).

Table 4: Mechanical properties for sandy soil

\begin{tabular}{|c|c|c|c|c|c|}
\hline Soil/Prop. & Saturated density & Elastic Modulus & Poisson & c & $\Phi$ \\
\hline \multirow{2}{*}{$\begin{array}{l}\text { Medium } \\
\text { Sand }\end{array}$} & $\mathrm{kN} / \mathrm{m}^{3}$ & $\mathrm{MPa}$ & Ratio & $\mathrm{kPa}$ & (degree) \\
\hline & 17.5 & 10 & 0.3 & 0 & $29^{\circ}$ \\
\hline
\end{tabular}

Where:

c: is the cohesive strength

$\Phi:$ is the angle of internal friction

\section{COMPUTATION PROCEDURE}

\section{Applied operators:}

FINAL is called to analyze it and check the safety constraints, stresses and The developed steady-state Genetic Algorithm starts with generating randomly an initial population of eight individuals. For every randomly generated solution, the structural analysis program deformations. Solutions are encoded to binary form to facilitate the application of mating operators. Genetic Algorithm's mating operators are crossover and mutation. Each two solutions are mated together to produce two children solutions. Like their parents, the new chromosomes (children) are decoded to decimal form. The structural analysis program is called to analyze and check these chromosomes. The program reads the induced stresses and deformation values and compare them to the allowable limits. Unsafe solutions get penalty 
function; their evaluation value (system total weight) is multiplied by 10 to increase their target weight. All parents and children solution are collected in one pool and sorted in an ascending order. The best 8 solutions which have less weight are selected to be new parents for the next generation. According to the assumed alternatives for every variable, the total number of possible solutions (chromosomes) = $12 * 8 * 8 * 5 * 5 * 2=38400$. The analysis consumes 48 hours on a moderate computer specification (Core I3 processor, $2.0 \mathrm{GHz}$ speed and $2 \mathrm{~GB}$ RAM). Figure (4) shows the structural overall cost progression through generations for different analysis times.

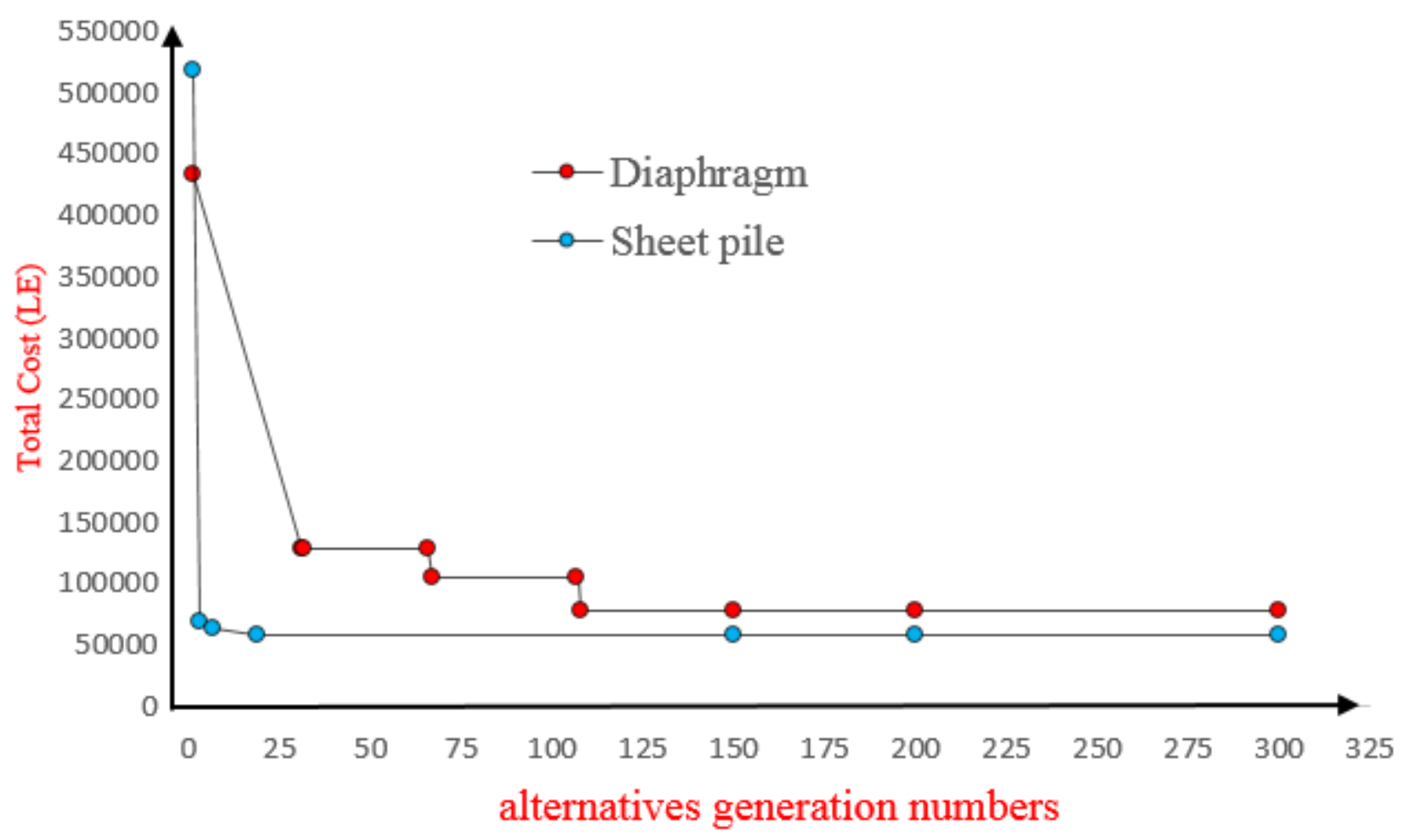

Fig.4: Plot of Total Cost (LE) Vs Generation Number

\section{Resulted Geometry}

Figure 5-a, 5-b shows the resulted mesh after 300 generations. Reaching the optimal solution may need thousands of generations which will also be good when compared to the number of alternatives. 


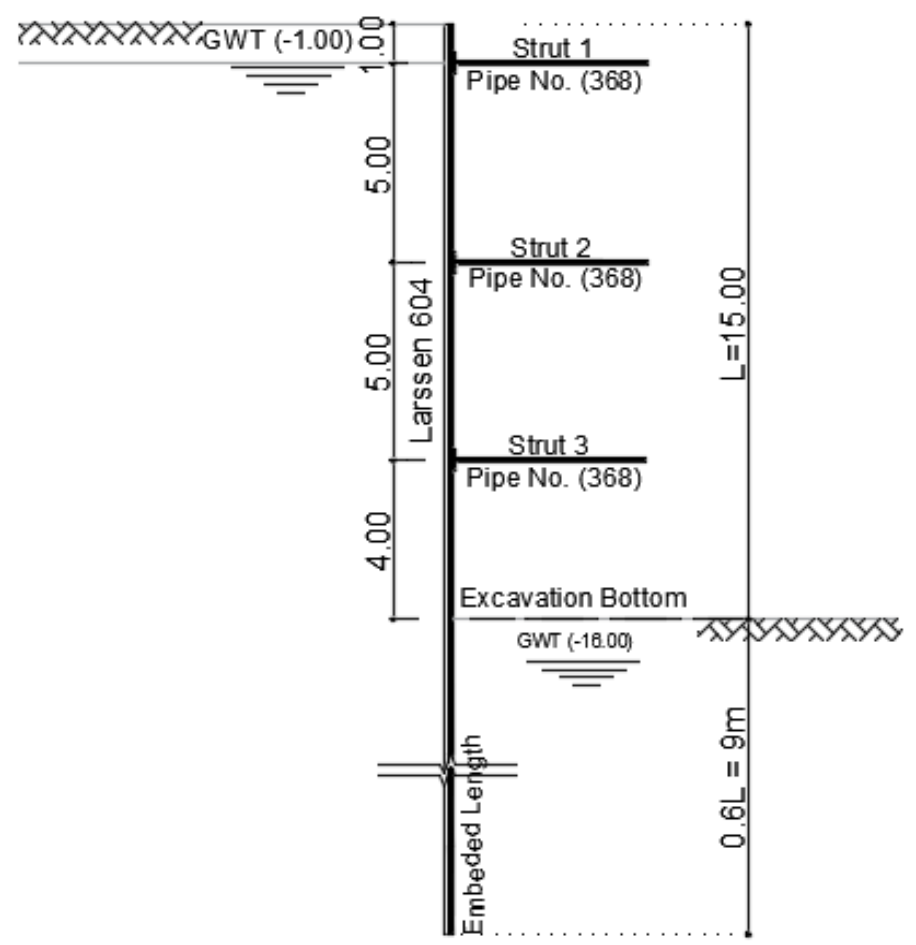

Fig.5.a : Optimal solution for sheet pile wall

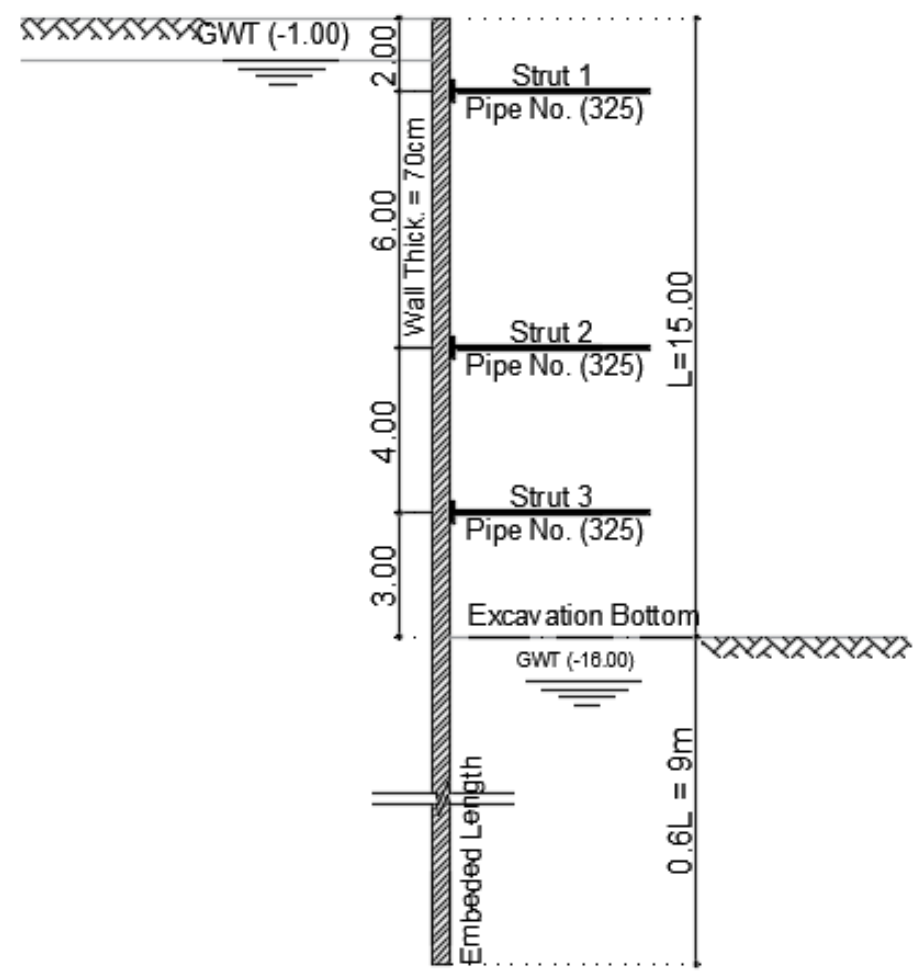

Fig.5.b : Optimal solution for concrete diaphragm wall

Figure 6-a, 6-b shows comparison between the cost of diaphragm wall and the sheet pile wall. This comparison is derived based on the ratio of steel cost to concrete cost. These figures show that the cost of steel sheet pile is less than the cost of diaphragm walls, when the ratio of the steel to concrete not more than 7 . The cost of diaphragm wall become less than the cost of steel sheet pile, when the ratio of steel to concrete is more than 7 . 


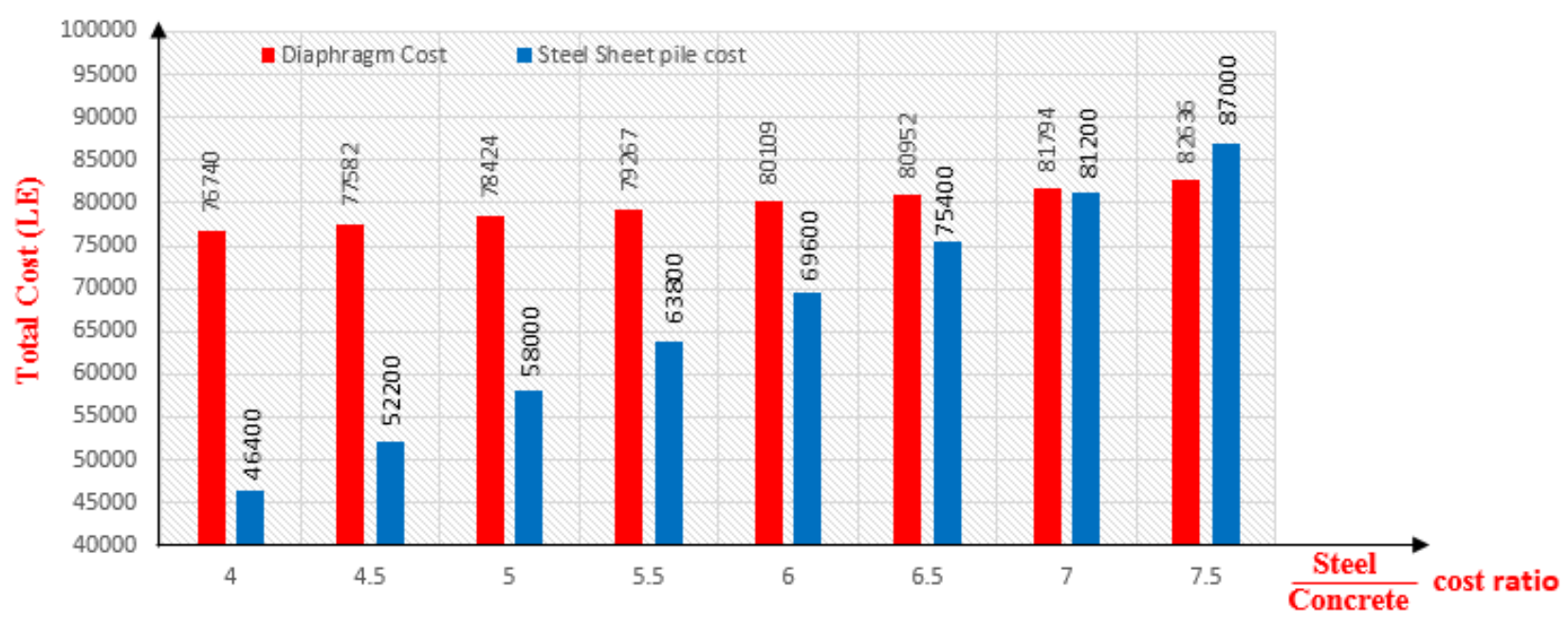

(a)

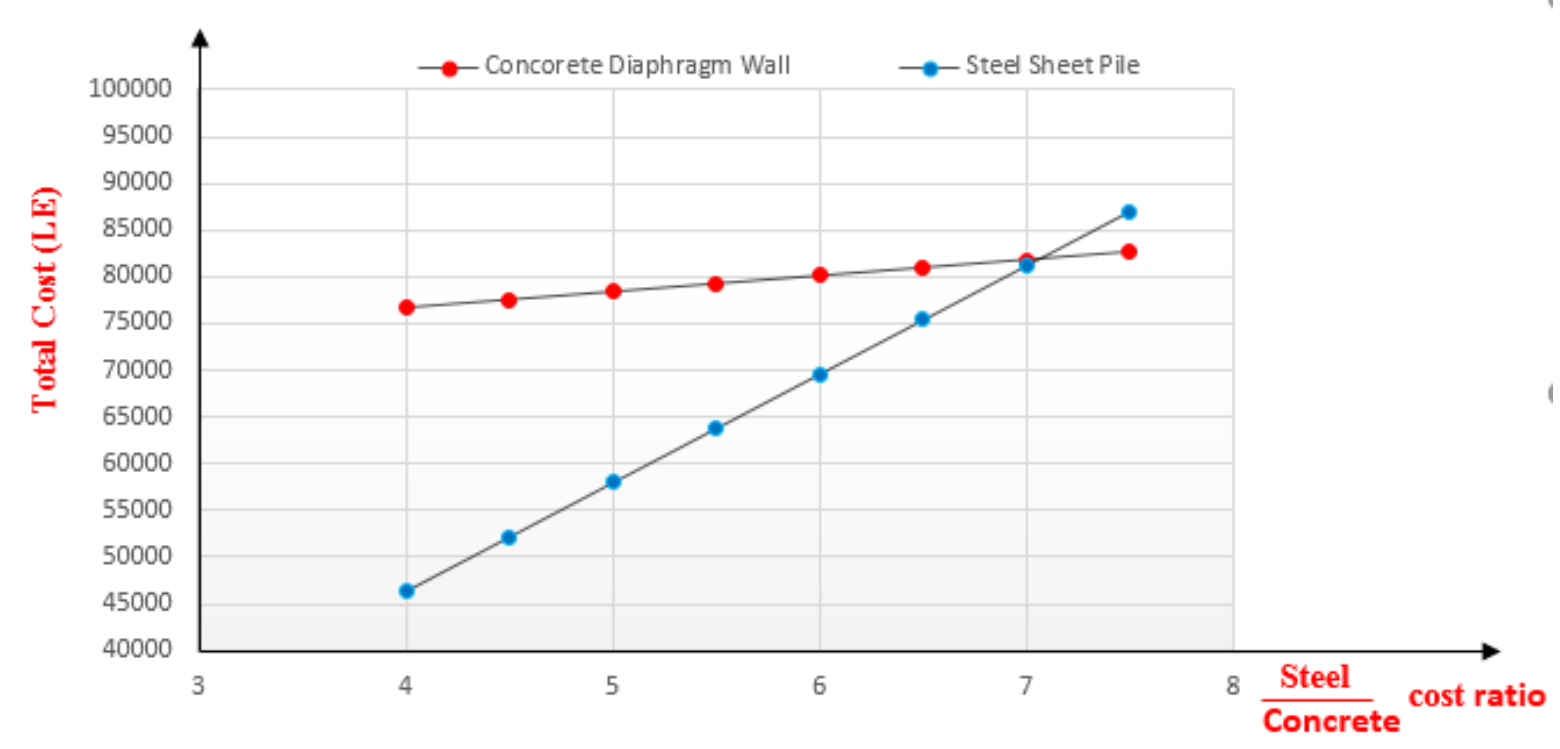

(b)

Fig.6: Compassion between the cost of conc. diaphragm wall and steel sheet pile wall

\section{CONCLUSIONS}

The developed algorithm can find optimal profile with safe stress and deformations. This algorithm comprises many parameters those cannot be included in traditional design method. The proposed optimization methodology proved to be successful technique to investigate structural optimization process. It can reach sufficiently the optimal solution with reasonable computation cost. This optimization tool can be adapted to work on different soil types and different excavation depths. The optimization process aims to reduce the material cost. The research showed that, Larsen 604 is the optimal 
section for sheet pile wall and pipe No. (368) is the optimal section for strut. Wall section No. (4) is the optimal section for concrete diaphragm wall and pipe No. (325) is the optimal strut section. Tables 5 summarize the search results.

Table 5: Summary of results

\begin{tabular}{c|c|c|c|c|c|c|c}
\hline Wall Type & WEL & WS & SS & $\begin{array}{c}\text { S.(1) } \\
\text { Position }\end{array}$ & $\begin{array}{c}\text { S. (2) } \\
\text { Position }\end{array}$ & $\begin{array}{c}\text { S.(3) } \\
\text { Position }\end{array}$ & $\begin{array}{c}\text { Total Cost } \\
\text { (L.E) }\end{array}$ \\
\hline Sheet Pile & $9 \mathrm{~m}$ & $\begin{array}{c}\text { Section } \\
\text { No. (5) }\end{array}$ & $\begin{array}{c}\text { Pipe } \\
\text { No. (4) }\end{array}$ & $1 \mathrm{~m}$ & $6 \mathrm{~m}$ & $11 \mathrm{~m}$ & 71540 \\
\hline Diaphragm wall & $9 \mathrm{~m}$ & $\begin{array}{c}\text { Section } \\
\text { No. (4) }\end{array}$ & $\begin{array}{c}\text { Pipe } \\
\text { No. (1) }\end{array}$ & $2 \mathrm{~m}$ & $8 \mathrm{~m}$ & $12 \mathrm{~m}$ & 74642 \\
\hline
\end{tabular}

Where:

WEL : is the wall embedded length.

WS : is the wall section.

$\mathrm{SS} \quad$ : is the strut section.

S.(1) : is the position of strut (1) from the ground surface.

S.(2) : is the position of strut (2) from the ground surface.

S.(3) : is the position of strut (3) from the ground surface.

\section{REFERENCES}

[1] A. I. Mana, G. W. Clough, G.W. 1981. Prediction of movements for braced cuts in clay.

Journal of Geotechnical Engineering, American Society of Civil Engineers, vol. 107, pp. 759-777, 1981.

[2] S.S. Chowdhury, K. Deb, A. Sengupta, Estimation of Design Parameters for Braced Excavation: Numerical Study. International Journal of Geomechanics, 13(3), pp.234-247, 2012.

[3] M. A. Eid, and R. Isaac, Application of Genetic Algorithms to Strutted Sheet Pile Design Optimization: VII European Congress on Computational Methods in Applied Sciences and Engineering M. Papadrakakis, V. Papadopoulos, G. Stefanou, V. Plevris (eds.) Crete Island, Greece, 510 June 2016.

[4] L. Rutkowski, Computational Intelligence: Methods and Techniques. Springer, 2008.
[5] D. E. Goldberg, Genetic Algorithms in Search, Optimization and Machine Learning. $\quad$ Addison-Wesley Publishing Company, Inc., NY., 1989.

[6] J. Holland, Adaptation in Natural and Artificial Systems ( $\left.2^{\text {nd }} e d.\right)$. The University of Michigan Press: Michigan, 1975; MIT Press: Cambridge, MA, 1992.

[7] G. Swoboda, Programmsystem FINAL, Finite Element Analysis Linearer und Nichtlinearer Stukturen, Version 7.1, Druck Universität Innsbruck, Austria, 2001.

[8] N. Turkkan, Discrete Optimization of Structures Using a Floating Point Genetic Algorithm. Annual Conference of the Canadian Society for Civil Engineering, Moncton, Nouveau - Brunswick, Canada, GCM-134/1-8, 2003.

[9] T. G. Bautechnik, Sheet piling Handbook. ThyssenKrupp Services, 2007. 
[10] M. A. Eid, M. Z. Abdelrehim, F. A. Elkashef and G. Swoboda, Optimization of Ground Improvement Techniques in Tunnelling Using Genetic Algorithms, 5th European Conference on Computation Mechanics (ECCM 2010), Paris, France, May 2010 


\section{التصميم الأمثل للحوائط اللوحية المقيدة}

الحوائط اللوحية المقيدة تعثبر حل أقتصادى شائع الاستخدام لسند جوانب الحفر ذات الأعماق الكبيرة وذلك عندما يكون الحفر مفتوحاً وغير مسموح بعمل ميول جانبية. تنتخدم هذه الأنظمة بشكل أساسى لتجنب الإنهيارات المختلفة التى قد تحدث لأساسات المبانى المجاورة لمنطقة الحفر ـ كما أن تكلفة هذه الأنظمة تعتمد بشكل رئيسى على نوع تربة الموقع وعلى عمق الحفر المطلوب الوصول إليه. وحيث أن تكلفة هذه الأنظمة عالية جدا كان من المهم الوصول بهذه الانظمة إلى تصميم بأقل تكلفة ممكنة ويحقق أعلى درجات الآمان من ناحية الحركة الأفقية للنظام والتى قد تؤثر على المبانى المجاورة و أيضا

$$
\text { الإجهادات المتولدة فى كلاً من الحائط والتربة. }
$$

هذه الدراسة تقدم التحليل والتصميم الأمنل لنلاك الأنظمة فى حالة التربة الرملية مع عمق حفر 15 منر تحت سطح الأرض. تم استخدام تطبيقاً للحاسب الآلي يعتمد على طريقة خوارزمية الجينات لإيجاد الحل الأمتل ودمج هذا البرنامج مع برنامج آخر للتحليل الإنشائي يعتمد على طريقة العناصر المحدة في تحليلها ومن ثم الوصول إلى الحل الأفضل. تم استخدام خوارزمبة الجينات كاسلوب حل للوصول الى الحل الأمتل، كما أنه تم عمل مقارنة بين استخدام أنواع مختلفة من الحوائط من ناحية المادة المصنعة منها، حيث تم استخدام نوعين من الحوائط وهما: الأول عبارة عن حوائط معدنية مقيدة والثانى حوائط مقيدة من الخرسانة المسلحة ، وتمت المقارنة بينهما من ناحية التكلفة. وقد تبين أن استخدام قطاع حائط رقم (5) و ثلاث دعامات أفقية بقطاع رقم (4)، عند أعماق 1منر، 6منز، 11منر من سطح الأرض، هى الحل الأفضل فى حالة الحوائط المعدنية المقيدة. بينما القطاع رقم (4) وثلاث دعامات أفقية بقطاع رقم (1)، عند أعماق 2متر 6 6ثر ، 12متر من سطح الأرض، هى الحل الأفضل فى حالة الحوائط الخرسانية المقيدة. ثم أظهرت النتائج أن تكلفة الحوائط المعدنية المقيدة أقل من تكلفة الحوائط الخرسانية المقيدة. 